Jurnal PG-PAUD Trunojoyo : Jurnal Pendidikan dan Pembelajaran Anak Usia Dini, Volume 7, Nomor 2, Oktober 2020 hal 33 - 43, ISSN : 2528-3553 (online), ISSN: 2407-4454 (print)

\title{
SENI TARI SEBAGAI CARA MEMPERBAIKI SUASANA HATI ANAK DI KB \& TK INDRIYASANA
}

\author{
Jamuna Ulfah ${ }^{1}$ \\ ${ }^{1}$ PIAUD Universitas Islam Negeri Sunan Kalijaga Yogyakarta \\ Jalan Marsda Adisucipto, 55281, Yogyakarta Indonesia \\ Email: una0na14@gmail.com \\ Received (Juni), Accepted (September), Published (Oktober)
}

\begin{abstract}
The Dance as $\boldsymbol{A}$ Way to Improve Children's Moods in Indriyasana Kindergarten. Early children have many different characteristics. The sort concentration is one of the many characteristics. It will certainly affect a child's intelligence and success in absorbing and receiving schooling. The shortness of concentration in the classroom profoundly affects the mood and tends to create an unstable class dimension. Because children can only absorb learning if they are in a good mood without being bored and depressed. This research aims to explain how the role of dance can play in improving the mood of children in Indriyasana Playgroup and Kindergarten Group at Yogyakarta. The study uses descriptive qualitative methods with basic data based on interviews, observation, and documentation. The art of dance is not performed daily but is scheduled for a week or two and is performed between hours of study at school. The art of dance at birth control Indriyasana Playgroup and Kindergarten Group at Yogyakarta. This is demonstrated by observing the comparative dimensions of the class and the concentration of the child as he observed the learning within the class before and after the art of dance. And the results showed that the concentration and focus of children were longer and they looked more cheerful than they had been before they entered the art of dance.
\end{abstract}

Keywords: Dance Art, Early Childhood Moods, Kindergartens

\begin{abstract}
Abstrak: Seni Tari sebagai Cara Memperbaiki Suasana Hati Anak di KB \& TK Indriyasana. Anak usia dini memiliki banyak karakteristik yang berbeda-beda. Konsentrasi yang pendek, merupakan satu dari sekian banyak karakteristik tersebut. Hal tersebut tentu akan sangat mempengaruhi kecerdasan dan keberhasilan anak dalam menyerap dan menerima pembelajaran di sekolah. Pendeknya konsentrasi di dalam kelas sangat mempengaruhi suasana hati dan cendrung menciptakan dimensi kelas yang tidak kondusif. Karena, anak hanya akan bisa menyerap pembelajaran jika mereka berada dalam keadaan senang hati tanpa merasa bosan dan tertekan. Sehingga penelitian ini bertujuan untuk memaparkan bagaimana peran dari seni tari dalam memperbaiki suasana hati anak usia dini di KB \& TK Indriyasana Yogyakarta. Penelitian ini menggunakan metode kualitatif deskriptif dengan data pokok bersumber dari hasil wawancara, observasi dan dokumentasi. Seni tari tidak dilaksanakan setiap hari melainkan dijadwalkan selama seminggu 2-3 kali dan dilaksanakan diantara jam-jam pembelajaran di sekolah. Seni tari di KB \& TK Indriyasana berhasil mengembalikan semangat dan kejenuhan anak ketika melaksanakan proses pembelajaran di sekolah. Hal ini dibuktikan dengan hasil observasi berupa perbandingan dimensi kelas dan tingkat konsentrasi anak saat memperhatikan pembelajaran di dalam kelas sebelum dan sesudah seni tari berlangsung. Dan hasilnya memperlihatkan bahwa tingkat konsentrasi dan fokus anak lebih lama dan mereka terlihat lebih ceria dibandingkan dengan sebelum mereka mengikuti kegiatan seni tari.
\end{abstract}

Kata kunci: Seni Tari, Suasana Hati Anak Usia Dini, Taman Kanak-Kanak

Copyright (c) 2020 Jamuna Ulfah 
Jurnal PG-PAUD Trunojoyo : Jurnal Pendidikan dan Pembelajaran Anak Usia Dini, Volume 7, Nomor 2, Oktober 2020 hal 33 - 43, ISSN : 2528-3553 (online), ISSN: 2407-4454 (print)

\section{PENDAHULUAN}

Anak usia dini berada pada usia yang fundamental untuk mendapatkan stimulasi, perhatian, pendidikan secara kompleks. Menurut NAEYC (National Association for The Education of Young Children) mengungkapkan anak usia dini adalah anak yang berada pada rentang usia 0-8 tahun yang tercakup dalam program pendidikan di taman penitipan anak, penitipan anak pada keluarga atau family child care home, pendidikan prasekolah baik swasta maupun negeri, TK dan SD. Sedangkan menurut UU RI No. 2 Tahun 2003 mengenai SISDIKNAS Pasal 1 ayat 14 menyatakah bahwa PAUD adalah suatu upaya pembinaan yang ditujukan pada anak sejak lahir sampai dengan usia enam tahun yang dilakukan dengan memberikan rangsangan sebanyak mungkin untuk menyukseskan tumbuh kembang anak serta meimiliki kesiapan memasuki pendidikan lanjut (DEPDIKNAS, 2003).

Definisi tersebut memiliki perbedaan pada rentang usia penyebutan anak yang masuk dalam kelompok usia dini. Walau berbeda namun makna dari kedua definisi tersebut memiliki kesamaan pada hal lingkup penamaan jenjang pendidikannya. Anak usia dini merupakan manusia kecil yang memiliki potensi yang masih harus dikembangkan. Seperti karakteristik tertentu yang khas dan tidak sama dengan orang dewasa yaitu selalu aktif, dinamis, antusias dan ingin tahu terhadap apa yang dilihat, didengar, dirasakan, mereka seolah-olah tak pernah berhenti bereksplorasi dan belajar (Sujiono, 2009). Karakteristik yang lain juga terlihat dari hati yang polos dan sikap yang cendrung berubah sesuai dengan usianya dalam kurun waktu yang sangat cepat. Hal tersebut, perlu menjadi perhatian bagi semua orangtua serta pendidik yang memberikan andil terbesar dalam menyukseskan tumbuh kembang mereka.

Suasana hati dalam hal ini masuk ke dalam aspek pengelolaan emosi bagi diri anak. Maka dari itu, mempelajari tumbuh kembang emosional anak menjadi suatu hal yang tidak kalah pentingnya. Emosional merupakan salah satu aspek yang turut dimasukkan dalam UU pendidikan PAUD dan disandingkan dengan aspek sosial karena keduanya memang sangat sulit untuk dipisahkan. Hal ini tercantum secara lebih rinci dalam PERMENDIKNAS No.58 Tahun 2009 tentang Standar PAUD yang kemudian diterangkan lebih rinci dalam PERMENDIKBUD No. 137 tahun 2014 tentang Standar Nasional PAUD dalam pasal 10. Dalam pasal 10 menjelaskan lebih rinci mengenai aspek perkembangan sosial emosional yang dibagi menjadi tiga poin penting yaitu: a) kesadaran diri memperlihatkan kemampuan diri, mengena perasaan sendiri dan mengendalikan diri, serta mampu menyesuaikan diri dengan orang lain; b) rasa tanggung jawab untuk diri dan orang lain, mencakup kemampuan mengetahui hakhaknya, menaati aturan, mengatur diri sendiri, serta bertanggung jawab atas perilakunya untuk kebaikan bersama; dan c) perilaku prososial mencakup kemampuan bermain dengan teman sebaya, memahami perasaan, merespon, berbagi, serta menghargai hak dan pendapat orang lain, bersikap kooperatif, toleran, dan berperilaku sopan. (PERMENDIKBUD, 2014).

Begitu kompleksnya penjabaran mengenai aspek perkembangan emosional anak dalam pasal tersebut yang menandakan bahwa aspek emosional anak sangat penting untuk dikemangkan dan diperhatikan. Pada dasarnya emosional seseorang merupakan salah satu faktor penting yang membentuk sifat dan kepribadian untuk tumbuh menjadi pribadi yang beradab dan beragama. Pengelolaan emosional yang baik juga menjadi hal yang diperhitungkan dalam dunia kerja seperti di era sekarang ini. Anak usia dini juga memiliki rentang fokus/konsentrasi yang begitu pendek.

Fokus yang dimaksud hanya berada pada rentang satu hingga satu setengah jam atau 
Jurnal PG-PAUD Trunojoyo : Jurnal Pendidikan dan Pembelajaran Anak Usia Dini, Volume 7, Nomor 2, Oktober 2020 hal 33 - 43 , ISSN : 2528-3553 (online), ISSN: 2407-4454 (print)

bisa kurang dari waktu tersebut. Ini merupakan satu dari sekian banyak karakteristik yang ada pada anak usia dini (Amini, n.d.). Berg dalam (Aisyah dkk., 2007) mengatakan bahwa "ketenangan anak usia dini dalam memperhtikan suatu hal hanya berada pada rentang waktu sekitar kurang lebih 10 menit, diluar dari segala hal yang ia senangi".

Hal ini juga wajib diketahui dan dipahami dengan semaksimal mungkin. Sehingga, seluruh proses belajar anak dapat lebih dioptimalkan. Anak lebih cepat merasakan bosan jika sistem belajar mengajar hanya berjalan begitu saja setiap harinya.

Sama dan tidak ada perubahan. Inovasi dan kreativitas dirasa sangat diperlukan dalam memberikan suasana baru bagi anak untuk merasa tetap betah, bahagia dan ceria berada lama-lama di sebuah lembaga pendidikan. Berbagai macam usaha, pikiran dan tenaga yang dilakukan dalam rangka memenuhi tuntutan-tuntutan tersebut dapat berupa penyediaan ekstrakurikuler atau yang lebih dikenal dengan tambahan di luar jam pelajaran bagi peserta didik dalam rangka memperluas pengetahuan dan meningkatkan kreativitas (Sularso, 2017). Selain dalam rangka meminimalisir kejenuhan dan kebosanan anak, fungsi lain dari kegiatan tambahan yaitu sebagai sarana perangsang/penstimulan hobi dan bakat anakanak. Maka dari itu, penelitian ini dilakukan dengan berdasarkan pada semua problema dan keresehan suasana pembelajaran di lembaga pendidikan seperti yang telah diuraikan sebelumnya.

Seni tari hadir sebagai salah satu kegiatan tambahan di luar jam pelajaran wajib di lembaga KB \& TK Indriyasana Yogyakarta. Menari dapat meningkatkan fungsi gerak pada anak dengan sempurna dan membuat anak merasa lebih leluasa karena kegiatan ini menggunakan musik dan suara-suara sebagai pendukung yang menstimulan indra pendengaran dan fungsi otak untuk merespon sehingga merangsang mereka untuk bergerak. Beberapa penelitian terdahulu juga menghubungkan kegiatan seni tari/menari dengan anak usia dini. Salah satu penelitian dalam Jurnal Pendidikan dan Kajian Seni yang berjudul "Menari sebagai Media Dance Movement Therapy (Dmt)" oleh Rahmawati dan kawan-kawan menyimpulkan bahwa kegiatan menari dapat menjadi salah satu media DMT pada anak mulai dari peningkatan integrasi antar beberapa aspek perkembangan, ekspresi kompetensi, peningkatan kesadaran diri, bentuk coping dari problema hidup dan terakhir peningkatan self-eficacy (Rahmawati, Wibowo, \& Lestari, 2018). Sedangkan dalam penelitian ini, penulis lebih menekankan pada peran seni tari dalam meningkatkan suasana hati anak yang lebih fokus kepada aspek emosional anak.

Made Utami Trisna Dewi juga melakukan penelitian yang berhubungan dengan "seni tari" yang berjudul "Manfaat Olah Tubuh Tari Sebagai Media Pengolahan Emosi Pada Anak Berkebutuhan Khusus Kategori Gifted : Sebuah Studi Kasus" pada jurnal UNY membahas seputar ABK kategori Gifted yang mendapatkan banyak manfaat setelah melaksanakan kegiatan menari dan salah satu hasilnya menyimpulkan bahwa "dengan menari, dapat mengungkapkan perasaan yang tidak dapat diungkapkan secara terbuka" (Trisna Dewi, 2018). Kesimpulan tersebut bermakna bahwa tarian menjadi sangat penting/urgent bagi seluruh manusia yang sukar untuk mengungkapkan perasaan dan segala bentuk tekanan yang dirasa. Sehingga penelitian ini masih memiliki kaitan dengan penelitian peneliti yang juga membahas aspek suasana hati/perasaan walau dengan tema dan tujuan yang berbeda. Membelajaran seni tari dapat mengembangkan seluruh aspek pada anak secara menyeluruh sehingga sangat memungkinkan untuk mengalahkan hasil akademis hingga anak beranjak dewasa karena terus menerus melekat pada anak 
Jurnal PG-PAUD Trunojoyo : Jurnal Pendidikan dan Pembelajaran Anak Usia Dini, Volume 7, Nomor 2, Oktober 2020 hal 33 - 43 , ISSN : 2528-3553 (online), ISSN: 2407-4454 (print)

sepanjang hidupnya (Akbar, EliyyilAbidin, 2018).

Berdasarkan pada kegiatan observasi di KB \& TK Indriyasana Yogyakarta, peneliti menyadari bahwa pendeknya konsentrasi anak di dalam kelas sangat mempengaruhi suasana hati mereka dan cendrung menciptakan suasana kelas yang tidak kondusif. Hal ini dikarenakan masih banyaknya dimensi kelas yang dipenuhi dengan aturan dan kewajiban yang memberikan batasan gerak pada anakanak untuk bebas bereksplorasi seperti tuntutan alami usianya. Sehingga kepala sekolah dan seluruh staf di KB \& TK Indriyasana sepakat untuk menambahkan pelajaran tambahan seni tari beberapa hari sekali dalam seminggu di sela-sela waktu pembelajaran anak. Karena mereka mulai mengerti, bahwa anak usia dini adalah sosok manusia aktif yang sulit untuk mengikuti peraturan secara terus menerus dan harus memiliki ruang serta waktu tersendiri bagi mereka untuk belajar dan mencurahkan segala emosinya.

\section{METODE PENELITIAN}

Metode penelitian merupakan bagian yang paling inti dari sebuah penelitian karena dijadikan sebagai suatu cara yang digunakan untuk melakukan seluruh rangkaian proses penelitian dengan semaksimal mungkin. Apabila cara yang digunakan tidak tepat, maka hasil dari sebuah penelitian tidak dapat memenuhi kriteria dari sebuah rumusan masalah yang telah dirancang sedemikian rupa. Dalam penelitian ini, metode yang digunakan adalah metode kualitatif deskriptif yang berfungsi menguraikan dan menjelaskan secara lebih terperinci mengenai sebuah kejadian yang menjadi titik fokus dari permasalahan yang telah dirumuskan.

Data yang bersifat kualitatif deskriptif berupa kegiatan seni tari dan kaitannya dengan suasana hati anak ketika telah merasa jenuh merasakan proses kegiatan belajar mengajar di dalam kelas menjadi titik temu dalam penelitian ini. Teknik analisis data yang digunakan yaitu teknik analisis data Miles dan Huberman. Data dikumpulkan melalui wawancara, observasi dan dokumentasi yang berkaitan dengan fokus masalah penelitian. Sumber data penelitian ini adalah guru tari, kepala sekolah dan tenaga pendidik. Data yang didapat diolah sesederhana mungkin guna menghasilkan hasil penelitian yang dapat menguraikan rumusan masalah secara lebih terperinci dan ringkas. Penelitian dilaksanakan di KB \&TK Indriyasana Depok

\section{HASIL DAN PEMBAHASAN}

Wawancara singkat yang dilakukan dengan kepala sekolah, guru tari dan tenaga pendidik di rapikan dengan menggunakan konsep screening melalui metode codding. Selain itu, pembicaraan ringan bersama beberapa orangtua juga mengungkapkan bahwa KB \& TK Indriyasana memiliki tenaga pengajar berkualitas dengan kuantitas yang baik, teratur, terkontrol dan terarah, serta berhasil mencetak lulusannya menjadi generasi cerdas, ceria dan berkualitas.

Hasil dari kegiatan observasi yang ditujukan dengan catatan kecil merangkum beberpaa poin penting yang dapat peneliti gunakan sebagai bahan rujukan penelitian dari lapangan secara valid. Poin-poin yang dimaksud yaitu yang pertama, dalam proses pembelajaran di kelas, anak yang mulai membuat ulah atau mengacaukan suasana kondusif diajak untuk bermain di luar kelas, dengan begitu anak yang lain tidak merasa terganggu dan masih tetap bisa fuokus mengikuti pembelajaran yang berlangsung. Poin kedua, ketika sudah masuk waktu pelajaran tambahan seni tari, anak-anak terlihat penuh kebahagiaan diwajah mereka sembari berbaris dan kemudian berlari menuju pendopo tempat menari dengan penuh kelincahan. Poin ketiga, ketika pelajaran 
Jurnal PG-PAUD Trunojoyo : Jurnal Pendidikan dan Pembelajaran Anak Usia Dini, Volume 7, Nomor 2, Oktober 2020 hal 33 - 43 , ISSN : 2528-3553 (online), ISSN: 2407-4454 (print)

tambahan seni tari berlangsung, anak-anak terlihat mengikuti gerakan dengan aktif dan energik tanpa merasa cape, lelah ataupun mengeluh. Mereka meloncat, berjingkrak, jongkok, merunduk dan bahkan berputar dengan penuh keceriaan. Poin keempat, menggambarkan betapa anak- anak dan orangtua sangat menikmati pembelajaran seni tari dengan riang dan bahagia. Mulai dari guru tari, anak-anak maupun tenaga pendidik semua ikut tersenyum dan tertawa tanpa beban dan tekanan selama pelajaran tambahan seni tari berlangsung.

Selanjutnya tahap dokumentasi. Dokumentasi yang peneliti lakukan ialah berupa pengambilan foto dan video menggunakan android Xiaomi Redmi 5A. pengambilan data tetap berkaitan dengan pelaksanaan tari bersama guru tari. Berikut ini foto-foto yang dimaksud.

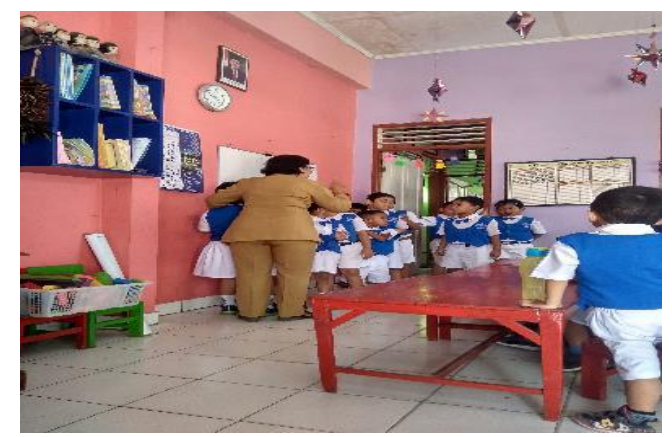

Gambar 1. Guru Mengarahkan Anak untuk Berbaris Sebelum Keluar Kelas dan Mengikuti Kegiatan Menari

Lembaga PAUD adalah lembaga yang paling dasar dalam mencetak generasi sebuah bangsa menjadi lebih baik atau malah sebaliknya. Lembaga inilah yang juga merupakan pendidikan pertama yang harus dijalani sebelum pendidikan-pendidikan yang lainnya. Setiap orang berhak memiliki hak untuk mengenyam pendidikan. Hal tersebut tertuang dalam beberapa landasan. Landasan yang dimaksud ialah:a) landasan yuridis; b) landasan filosofis; dan c) landasan keilmuan (Busthomi, 2012). Ini pula yang menjadikan pendidikan itu penting. Anak-anak yang berada dalam lembaga PAUD di Indonesia memiliki rentang usia 0-6 tahun. Usia ini merupakan masa peka atau lebih dikenal dengan istilah golden age yang sangat menentukan mereka kelak ketika dewasa baik dari segi fisik, mental maupun kecerdasan (Atabik and Burhanuddin, 2015).
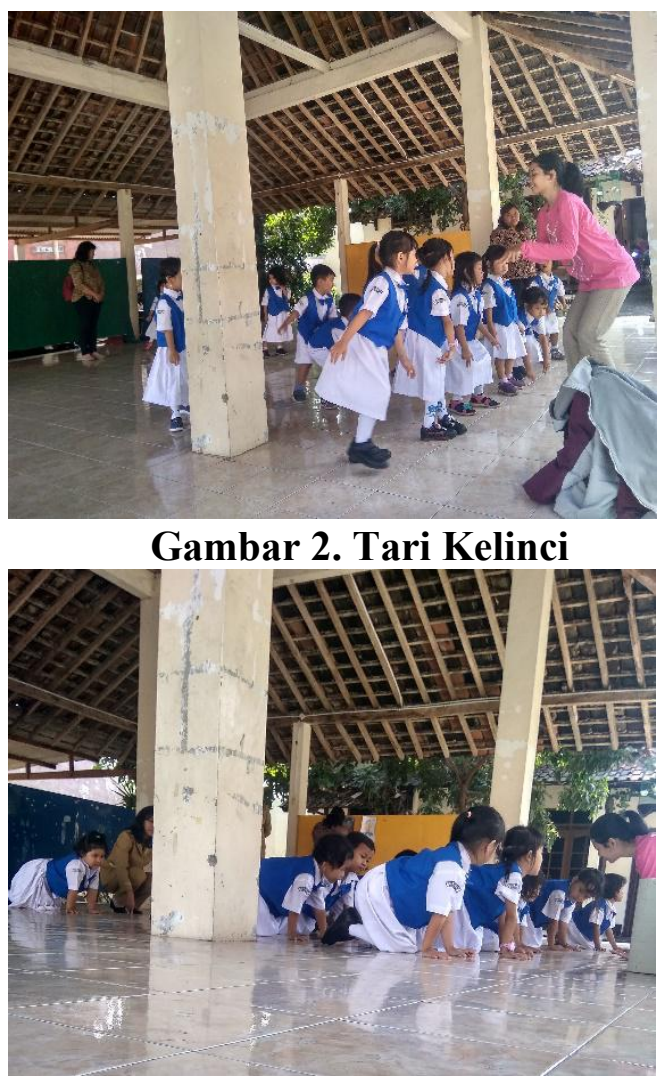

Gambar 3. Tari Kucing

Pemerintah, orangtua dan masyarakat berlomba-lomba dan saling bekerjasama untuk bisa mewujudkan semua angan dan cita-cita bangsa yang cerdas, berakhlak dan beradab. Semua upaya dilakukan untuk mewujudkannya. Mulai dari mendirikan lembaga seindah mungkin, menyediakan program-program kurikulum semenarik mungkin, hingga mempekerjakan tenaga pendidik yang berkualitas. Namun, semua itu belum cukup untuk bisa memenuhi kebutuhan dan keinginan anak sebagai figur yang menikmati semua sarana tersbut. Abraham 
Jurnal PG-PAUD Trunojoyo : Jurnal Pendidikan dan Pembelajaran Anak Usia Dini, Volume 7, Nomor 2, Oktober 2020 hal 33 - 43, ISSN : 2528-3553 (online), ISSN: 2407-4454 (print)

Maslow mengusung teori kebutuhan, setidaknya ada lima kebutuhan yang harus dipenuhi yaitu: a) kebutuhan fisiologis; b) kebutuhan akan rasa aman; c) kebutuhan memiliki dan cinta; d) kebutuhan akan adanya rasa percaya diri yang dimilikinya; dan e) kebutuhan untuk dapat mengaktualisasikan diri (Wiyani, 2014). Salah satu cara mengaktualisasikan diri adalah dengan menari.
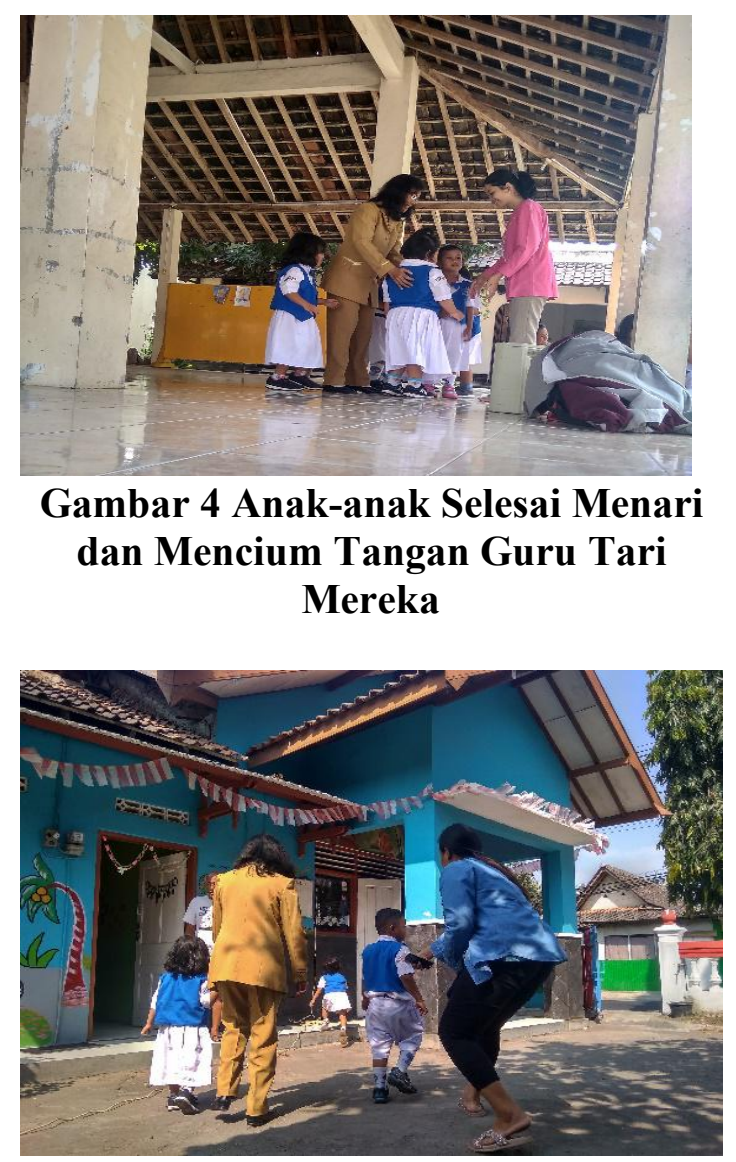

Gambar 5. Orangtua dan Guru yang Menggiring Anak-anak Masuk Kembali ke Dalam Kelas

Anak usia dini memiliki aspek pertumbuhan dan perkembangan yang tidak kalah penting untuk diperhatikan dan dimasukkan dalam program kegiatan suatu lembaga pendidikan anak. Pertumbuhan dan perkembangan itu merupakan sifat kodrat manusia yang harus mendapat perhatian secara seksama (Sunarto \& Hartono, 2013). Proses tumbuh kembang tersebut dijelaskan oleh Kementrian Pendidikan dalam KEMENDIKBUD No. 137 tahun 2014 tentang Standar Nasional PAUD dalam pasal 10. Dimana aspek perkembangan tersebut terjadi seiring proses pembelajaran di dalam dan di luar kelas. Setiap lembaga pendidikan tentu memiliki ruang kelas. Ruang tersebut merupakan ruangan yang setiap hari ditempati dalam kurun waktu setengah tahun dari kehidupan manusia dalam menempuh pendidikan.

Untuk anak usia dini, ruangan kelas wajib di desain sedemikian rupa untuk menstimulasi anak berimajinasi dan bahagia berada di dalamnya. Namun tak dapat dipungkiri, anak usia dini terlahir sebagai sosok unik yang memiliki ragam karakteristik yang berbedabeda di tiap-tiap anaknya. Karakteristik anak usia dini yaitu: a) memiliki rasa ingin tahu yang besar; b) merupakan pribadi yang unik; c) suka berfantasi dan berimajinasi; d) masa paling potensial untuk belajar; e) menunjukkan sikap egosentris; f) memiliki rentang daya konsentrasi yang pendek; dan g) sebagai bagian dari makhluk sosial (Hartati, 2005).

Pada poin $\mathrm{f}$, anak memiliki rentang daya konsentrasi yang pendek, hal ini didukung oleh Andayani (2015), ia mengungkapkan bahwa "pada umumnya anak usia dini masih cepat bosan belajar dan berlatih, seluruh kegiatannya ditentukan oleh suasana hati dimana ia menyenangi hal-hal yang indah, berwarna-warni, menggembirakan dan diperlihatkan dengan mengumbar daya imajinasi yang tinggi dan liar". Pernyataan tersebut memberikan penjelasan bahwa pendidikan anak usia dini tidak bisa disamakan dengan pendidikan anak di usia lainnya. Kepekaan guru dalam merasakan berbagai suasana hati anak menjadi prioritas utama dalam menyukseskan belajar mengajar di lembaga PAUD yang dibuktikan dengan kecepatan pemberian respon maupun tanggapan (Gandana, n.d.). 
Jurnal PG-PAUD Trunojoyo : Jurnal Pendidikan dan Pembelajaran Anak Usia Dini, Volume 7, Nomor 2, Oktober 2020 hal 33 - 43, ISSN : 2528-3553 (online), ISSN: 2407-4454 (print)

Suasana hati masuk ke dalam kategori aspek emosional. Emosi, secara bahasa diartikan sebagai luapan perasaan yang kian berkembang dan surut dalam waktu yang singkat, yang berada dalam keadaan dan reaksi psikologis serta fisiologis (Alwi and dkk, 2002). Sedangkan Aliah B. Purwakania (2006) membagi emosi menjadi dua macam yaitu emosi primer (gembira, sedih, marah, takut) dan emosi sekunder (malu, iri hati, dengki sombong, angkuh, bangga, kagum, takjub, benci, cinta, bingung, terhina, sesal, mandiri, toleran, patuh, simpati, empati, dll).

Selain usia ini merupakan masa pembentukan jati diri anak secara menyeluruh, usia ini juga harus diimbangi dengan sistem pendidikan yang kreatif dan inovatif yang selalu menuntut pendidiknya untuk bisa memutar otak sedemikian rupa dalam menjalankan proses belajar mengajar anak. Dengan tujuan utama anak belajar menggunakan konsep "belajar sambil bermain" sehingga ia bisa merasa bahagia dan pembelajaran tidak akan menjadi suatu hal yang sia-sia. Kepiawaian pendidik dalam hal menciptakan proses pembelajaran yang mempesona serta mengkreasikan metode dan sarana yang mampu membuat mereka asyik belajar, bermain, melakukan sesuatu dengan penuh variasi yang memadai menjadi kewajiban pokok yang harus selalu dilaksanakan (Andayani, 2015).

Sebelumnya telah dijelaskan bahwa anak memiliki imajinasi yang tinggi dan liar. Imajinasi tersebut harus dikembangkan sedemikian rupa sesuai dengan tujuan Pendidikan Nasional dalam UU No. 20 tahun 2013 tentang SISDIKNAS yaitu berfungsi mengembangkan kemampuan dan membentuk watak serta peradaban bangsa yang bermartabat dalam rangka mencerdaskan kehidupan bangsa, mengembangkan potensi untuk menjadi manusia beriman dan bertakwa kepada Tuhan Yang Maha Esa, berakhlak mulia, sehat, berilmu, cakap, kreatif, mandiri, dan menjadi warga negara yang demokratis serta bertanggung jawab. Seni tari dapat dijadikan sebagai salah satu cara untuk mewujudkan tujuan Pendidikan Nasional tersebut.

Seni merupakan salah satu bidang pengembangan yang bertujuan agar anak mampu menciptakan dan menghargai sebuah karya dari hasil imajinasinya dengan berdasarkan pada kepekaan serta kreativitas anak (Munawaroh, 2017). Sedangkan seni tari menurut Bagong Kussudiarjo adalah keindahan bentuk dari anggota badan manusia yang bergerak, berirama, musik dan berjiwa yang harmonis (Aminuddin, 2015). Beberapa pendapat mengenai definisi tari dari para pakar memiliki perbedaan. Seperti yang disampaikan oleh Susan K.Lenger bahwa "tari adalah gerak-gerak yang manusia ciptakan untuk dinikmati dalam bentuk curahan ekspresif" (Marsela, 2016).

Menurut Kamala Devi Chattopadhyaya yang merupakan ahli seni asal India mendefinisikan tari sebagai suatu insting atau desakan emosi di dalam diri manusia dan mendorongnya untuk mencari ekspresi pada tari"(Rahayu, 2018). Dan terakhir menurut La Mery dalam bukunya Dance Compotition menuliskan bawa "tari merupakan ekspresi berbentuk simbolis dalam wujud yang lebih tinggi dan harus diinternalisasikan" (Dwi Arini, dkk, 2008). Semua definisi tersebut memang berbeda-beda namun mengarah pada satu definisi yaitu gerakan yang mengandung emosi dan diekspresikan dengan menggunakan musik sehingga orang yang melihat dapaat ikut menikmatinya. Terlepas dari banyak ragamnya definisi seputar seni tari, seluruh definisi tersebut sangat cocok dengan dunia anak usia dini yang bermoto "Sehat, Cerdas, Ceria". Melalui tarian anak bisa merasakan kebahagiaan, keceriaan, kebebasan, dapat meningkatkan stimulasi sosial dengan orang lain, melatih konsentrasi anak dalam memperhatikan dan meniru gerakan, menselaraskan antara musik dan gerakan serta merangsang kreativitas anak 
Jurnal PG-PAUD Trunojoyo : Jurnal Pendidikan dan Pembelajaran Anak Usia Dini, Volume 7, Nomor 2, Oktober 2020 hal 33 - 43 , ISSN : 2528-3553 (online), ISSN: 2407-4454 (print)

untug bergerak aktif dan dinamis berdasarkan ritmenya.

Segala dampak positif tersebut mendukung kemudahan anak dalam menerima pembelajaran yang diberikan. Hamruni menyebutkan bahwa "belajar tidak pernah akan berhasil dalam arti yang sesungguhnya, bila dilakukan dalam suasana yang menakutkan, belajar hanya akan efektif, bila suasana hati anak didik berada dalam kondisi yang menyenangkan" (Hamruni, 2009). Begitu pentingnya suasana hati dalam memaksimalkan tumbuh kembang anak dalam belajar yang harus dipahami juga oleh semua pihak yang turut berkontribusi dalam dunia pendidikan anak.

KB \& TK Indriyasana adalah sebuah lembaga di Kecamatan Depok, Maguwoharjo Yogyakarta terakreditasi B yang berhasil bangkit dari keterpurukan mereka pasca bencana alam. Tanggal 27 Mei 2006 jam 05.55 terjadi gempa dahsyat di Yogyakarta sehingga KB \& TK Indriyasana mengalami kerusakan parah. Namun kejadian tersebut membawa berkah bagi lembaga karena mendapat bantuan dari Dinas / P2DT sebanyak 130 juta untuk membangun TK pendopo sebagai sarana pendidikan anak.

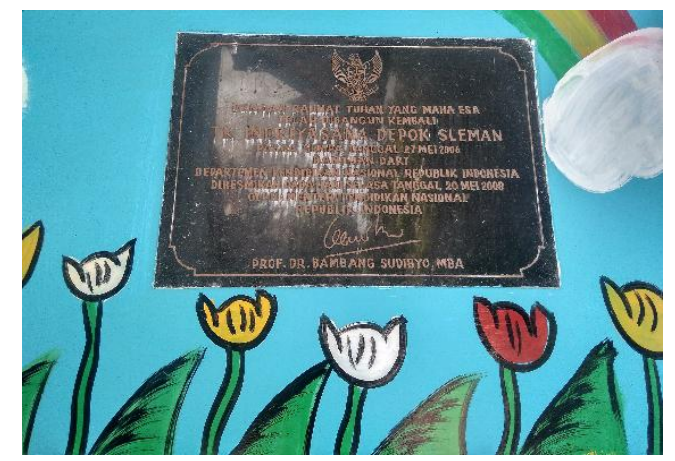

Gambar 6. Bukti Resmi Bantuan dari Departemen Pendidikan Nasional Republik Indonesia

Kualitas pendidikan juga sangat penting dalam memberikan mutu pelajaran, maka dari itu pengurus menyiapkan guru-guru yang berdedikasi tinggi dari lulusan sarjana pendidikan. Begitu juga untuk urusan seni tari, pengelola memilih seni tari yang benar-benar handal dan berkualitas untuk mengajarkan anak-anak di KB \& TK Indriyasana tersebut. Sehingga tarian yang diberikan dapat benarbenar memberikan stimulus bagi anak untuk tumbuh dan berkembang dengan ceria dan bahagia sesuai harapan.

Dokumentasi yang peneliti lakukan memiliki beberapa temuan. Pada gambar 1, terlihat seorang guru sedang mengarahkan anak untuk berbaris sebelum anak-anak keluar dan melaksanakan kegiatan menari. Kegiatan ini tidak hanya dilakukan dalam rangka keluar kelas sebelum menari tapi juga dalam rangka masuk ke dalam ruang kelas secara bersamasama, keluar dari ruang kelas untuk istirahat maupun pada jam pulang anak. Hasil wawancara dengan pelatih seni tari di Indriyasana mengungkapkan bahwa pemilihan tari kucing dan tari kelinci pada gambar 2 dan gambar 3 bukan tanpa alasan. Selain tarian ini sederhana, gerakannya begitu mudah untuk diikuti anak-anak, lantunan musiknya juga tergolong santai dan penuh dengan kegembiraan sehingga mendorong anak yang menari juga ikut bahagia, suka, tertawa dan ceria.

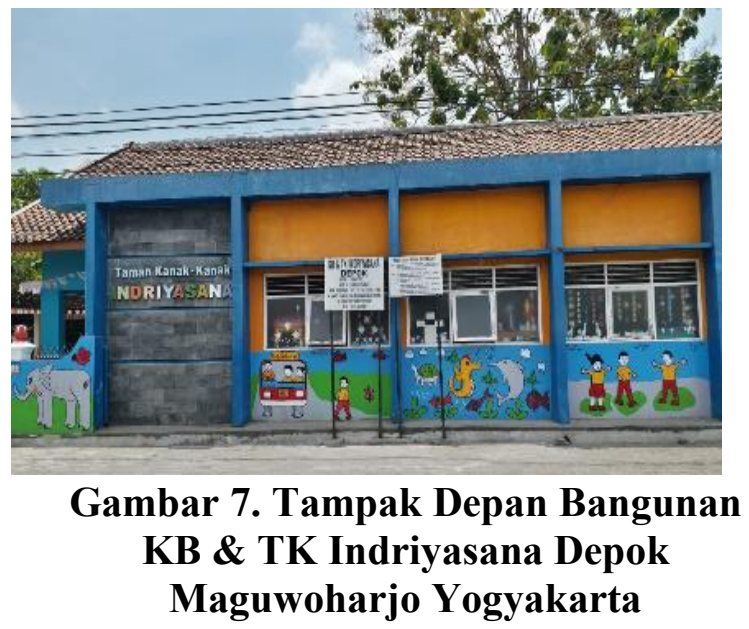


Jurnal PG-PAUD Trunojoyo : Jurnal Pendidikan dan Pembelajaran Anak Usia Dini, Volume 7, Nomor 2, Oktober 2020 hal 33 - 43, ISSN : 2528-3553 (online), ISSN: 2407-4454 (print)

Pernyataan ini didukung oleh Masganti (2017) yang mengungkapkan bahwa animal dance tari yang sangat cocok karena sesuai dengan karakteristik anak usia dini yaitu berupa tarian sederhana dengan musik penuh kegembiraan sehingga menstimulasi anak untuk mudah memahami gerakan serta bersemangat dalam menari. Selain menerapkan kegiatan menari, tidak lupa guru mengajarkan anak untuk mencuim tangan pelatih tari selesai kegiatan menari dilakukan yang diperlihatkan pada gambar 4 .

Salah satu guru mengungkapkan "kebiasaan ini, selalu kami lakukan dalam rangka menanamkan kesopanan, persatuan, dan bentuk kasih sayang antara pelatih tari dan anak-anak, walaupun pelatih tari tidak setiap hari bertemu anak-anak karena hanya dijadwalkan 2-3 kali dalam seminggu, namun anak-anak selalu menanti waktu seni tari dan kedatangan pelatih tari menjadi kebahagiaan dan keceriaan tersendiri bagi anak-anak di KB \& TK Indriyasana ini". Pada gambar 5, terlihat orangtua dan guru menggiring anakanak untuk kembali masuk ke dalam ruang kelas. Salah seorang orangtua murid mengungkapkan kebahagiaannya terhadap pihak lembaga KB \& TK Indriyasana. "Saya merasa sangat bahagia anak saya berada di sekolah ini, dia terlihat sangat senang ketika menari, guru yang penuh perhatian, temanteman yang menyayangi, peraturan yang sesuai dengan visi misi menjadikan sekolah ini benar-benar hidup dan dirindukan oleh setiap orangtua apabila telah tiba waktu libur dan masa kenaikan kelas anak-anak".

Observasi yang peneliti lakukan di lembaga $\mathrm{KB}$ \& $\mathrm{RA}$ Indriyanasari memperlihatkan perbedaan yang sangat signifikan. Hal ini dilaksanakan dalam perbandingan dua kejadian. Yaitu ketika pembelajaran berlangsung sebelum kegiatan seni tari dilaksanakan dan ketika pembelajaran berlangsung sesudah kegiatan seni tari dilaksanakan. Dalam pengamatan yang begitu sederhana ini, peneliti menemukan bahwa konsentrasi anak dalam memperhatikan, respon anak di dalam kelas, kesesuaian perintah dengan yang anak kerjakan, keceriaan diwajah anak dan terakhir kondusifitas kelas semua terjadi perubahan. Semua aspek dan poin tersebut terlihat lebih baik/mengalami peningkatan ke arah yang positif setelah anak selesai melaksanakan kegiatan menari.

Semua temuan-temuan dalam penelitian ini menunjukkan kebenaran kaitan antara suasana hati dan gerakan menari dalam mendukung kondusifitas pembelajaran anak usia dini. Campur tangan guru juga wajib diperhatikan dalam mendukung tujuan utama dari seni tari sebagai penstabilan kembali suasana hati anak akan kejenuhan dan kebosanannya di dalam ruang kelas. Sehingga selama kegiatan seni tari berlangsung guru wajib berada di sekitar anak untuk memperhatikan mereka dari kejauhan.

Anak tentu memiliki suasana hati atas apa yang dialaminya pada suatu kejadian tertentu. Berikan anak kesempatan untuk mencurahkannya sehingga ia dapat menuangkan segala perasaan dan emosi yang selama ini dipendam (Ndari and Chandrawaty, n.d.). Melalui tarian, maka anak dapat mencurahkan segala bentuk emosi itu dengan cara positif. Ciri khas kegiatan gerak berirama anak-anak ialah kebebasan berekspresi melalui berbagai macam gerakan yang disertai iringan musik, serta kemampuan anak dalam bergaya sesuai ekspresi diri sendiri (Oktari \& Marlina, 2019). Apabila sedari kecil anak tidak diberikan kesempatan untuk berekspresi serta mencurahkan dan melepaskan emosi yang dia rasakan. Maka, hal tersebut akan berdampak buruk terhadap psikis/kejiwaan anak yang akan sangat mempengaruhi tumbuh kembang kecerdasan maupun fisiknya. Dengan kata lain, ketika anak tersebut beranjak dewasa maka ia akan melampiaskan segala bentuk emosinya itu 
Jurnal PG-PAUD Trunojoyo : Jurnal Pendidikan dan Pembelajaran Anak Usia Dini, Volume 7, Nomor 2, Oktober 2020 hal 33 - 43, ISSN : 2528-3553 (online), ISSN: 2407-4454 (print)

dengan cara yang negatif/salah. Seperti minum-minuman keras, narkoba, seks dll.

\section{SIMPULAN DAN SARAN}

Seni tari di KB \& TK Indriyasana berhasil mengembalikan semangat dan kejenuhan anak ketika melaksanakan proses pembelajaran di dalam kelas. Terjadi kaitan antara suasana hati dan gerakan menari dalam mendukung kondusifitas pembelajaran anak usia dini. Hal ini dibuktikan dengan adanya perbandingan dua kejadian berbeda, dalam waktu yang berbeda, di hari yang sama, kelas yang sama, dan murid yang sama. Hasilnya, konsentrasi anak dalam memperhatikan, respon anak di dalam kelas, kesesuaian perintah dengan yang anak kerjakan, keceriaan diwajah anak dan terakhir kondusifitas kelas semua terlihat lebih baik/mengalami peningkatan ke arah yang positif setelah anak selesai melaksanakan kegiatan menari. Campur tangan guru juga wajib diperhatikan dalam mendukung tujuan utama dari seni tari sehingga selama kegiatan seni tari berlangsung guru wajib berada di sekitar anak untuk memperhatikan mereka dari kejauhan.

\section{DAFTAR PUSTAKA}

Aisyah, S. dkk. (2007). Materi Pokok Perkembangan Dan Konsep Dasar Pengembangan Anak Usia Dini. Jakarta: Universitas Terbuka.

Akbar, EliyyilAbidin, Jainal. (2018). "Pembelajaran Seni Tari Dalam Mewujudkan Aspek Perkembangan Anak Di Taman Kanak-Kanak Eliyyil Akbar." AWLADY: Jurnal Pendidikan Anak Vol. 4, (2).

Alwi, H. dkk. (2002). Kamus Besar Bahasa Indonesia. Jakarta: Balai Pustaka.

Amini, Mukti. (tt). "Hakikat Anak Usia Dini." In , 1-43.

Aminuddin, Isnu Rizka. (2015). "Program Pembelajaran Di RA Tiara Chandra Perdukuhan Prancak Panggungharjo Kecamatan Sewon Kabupaten Bantul
Yogyakarta." Fakultas Ilmu Pendidikan, Universitas Negeri Yogyakarta, August 2015.

https://core.ac.uk/download/pdf/3352599 6.pdf.

Andayani. (2015). Problema Dan Aksioma: Dalam Metodologi Pembelajaran Bahasa Indonesia. 1st ed. Vol. 1. Yogyakarta: Deepublish.

Atabik, Ahmad, and Ahmad Burhanuddin. (2015). "Prinsip Dan Metode Pendidikan Anak Usia Dini.” Jurnal ThufuLa 3 (2).

Busthomi, M. Yazid. (2012). Panduan Lengkap PAUD: Melejitkan Potensi Dan Kecerdasan Anak Usia Dini. Edited by Fahmi. Cet. 1. Citra Publishing.

Depdiknas. (2003). Undang-Undang RI Nomor 20 Tahun 2003 Tentang Sistem Pendidikan Nasional. Indonesia.

Dwi Arini, Sri Hermawati, \& dkk. (2008). Seni Budaya Untuk SMK. Jilid 2. Direktorat Pembinaan Sekolah Menengah Kejuruan Direktorat Jenderal Manajemen Pendidikan Dasar dan Menengah Departemen Pendidikan Nasional.

Gandana, Gilar. (tt). KOMUNIKASI TERAPEUTIK DALAM PENDIDIKAN ANAK USIA DINI: Panduan Bagi Guru, Calon Guru, Dan Orang Tua. Ksatria Siliwangi.

Hamruni. (2009). Edutainment Dalam Pendidikan Islam Dan Teori-Teori Pembelajran Quantum. Yogyakarta: Fakultas Tarbiyah UIN SUKA.

Hartati, S. (2005). Perkembangan Belajar Pada Anak Usia Dini. Jakarta: Dikti Depdiknas.

Masganti, M. (2017). "Upaya Meningkatkan Kemampuan Motorik Kasar Anak Usia 5-6 Tahun Melalui Kegiatan Menari Animal Chicken Dance." Tarbiyah UIN SUKA 5 (2).

Marsela, Y. (2016). "Implementasi Tarian Daerah Dengan Menggunakan Iclone (Studi Kasus: Tari Gambyong).” 
Jurnal PG-PAUD Trunojoyo : Jurnal Pendidikan dan Pembelajaran Anak Usia Dini, Volume 7, Nomor 2, Oktober 2020 hal 33 - 43 , ISSN : 2528-3553 (online), ISSN: 2407-4454 (print)

Fakultas Komunikasi Dan Informatika, Universitas Muhammadiyah Surakarta, 2016.

Munawaroh, H. (2017). "Implementasi Pembelajaran Tari Dalam Mengembangkan Aspek Perkembangan Anak Usia Dini." Golden Age: Jurnal Ilmiah Tumbuh Kembang Anak Usia Dini 2 (2): 25-34.

Ndari, S. S, \& Chandrawaty. (tt.). Telaah Kurikulum Pendidikan Anak Usia Dini. Edu Publisher.

Oktari, Henifo, and Serli Marlina. (2019). "Pengaruh Tari Ayam Modifikasi Terhadap Perkembangan Motorik Kasar Anak Di Taman Kanak-Kanak Jabal Rahmah Padang." Jurnal PG-PAUD Trunojoyo: Jurnal Pendidikan Dan Pembelajaran Anak Usia Dini 6 (1): 2934.

https://doi.org/10.21107/pgpaudtrunojoy o.v6i1.5375.

PERMENDIKBUD. (2014). PERMENDIKBUD No. 137 Tahun 2014 Tentang Standar Nasional Pendidikan Anak Usia Dini.

Purwakania Hasan, Aliah B. (2006). Psikologi Perkembangan Islami: Menyikapi Rentang Kehidupan Manusia Dan Prakelahiran Hingga Pascakematian. Jakarta: Rajawali Press.

Rahayu, Dwi. (2018). "Pengaruh Aktivitas Anak Menari Tari Ganau Terhadap Perkembangan Motorik Anak Usia Dini Di PAUD Dharma Wanita Persatuan Arga Makmur Bengkulu Utara." IAIN Bengkulu, 2018.

Rahmawati, Bangun Yoga Wibowo, and Dwi Junian Lestari. (2018). "Menari Sebagai Media Dance Movement Therapy (DMT)." Jurnal Pendidikan Dan Kajian Seni 3 (1): 31-46.

Sujiono, Y.N. (2009). Konsep Dasar Pendidikan Anak Usia Dini. Jakarta: Indeks.

Sularso, P. (2017). "Upaya Pelestarian
Kearifan Lokal Melalui Ekstrakurikuler Karawitan Di Smp Negeri 1 Jiwan Tahun 2016." Citizenship Jurnal Pancasila Dan Kewarganegaraan 5 (1): 1. https://doi.org/10.25273/citizenship.v5i1. 1181.

Sunarto, H., \& Agung B. Hartono. (2013). Perkembangan Peserta Didik. Jakarta: Rieneka Cipta.

Trisna. D, \& Made, U. (2018). "Manfaat Olah Tubuh Tari Sebagai Media Pengolahan Emosi Pada Anak Berkebutuhan Khusus Kategori Gifted: Sebuah Studi Kasus." E-Journal Universitas Negeri Yogyakarta.

Wiyani, N. A. (2014). Mengelola \& Mengembangkan Kecerdasan Sosial \& Emosi Anak Usia Dini: Panduan Bagi Orangtua \& Pendidik PAUD. Edited by Rose KR. Cet. I. Yogyakarta: AR-RUZZ MEDIA. 